\title{
Diabetes Mellitus Type 2 in Hospitalized COPD Patients: Impact on Quality of Life and Lung Function
}

\author{
Evgeni V. Mekov' ${ }^{1}$, Yanina G. Slavova ${ }^{1}$, Marianka P. Genova ${ }^{2}$, Adelina D. Tsakova ${ }^{2}$, Dimitar T. \\ Kostadinov' , Delcho D. Minchev' ${ }^{1}$, Dora M. Marinova' ${ }^{1}$, Mihail A. Boyanov ${ }^{3}$ \\ ${ }^{1}$ Clinical Center for Pulmonary Diseases, St. Sofia SHATPD, Sofia, Medical University of Sofia, Sofia, Bulgaria \\ ${ }^{2}$ Central Clinical Laboratory, Alexandrovska University Hospital, Sofia, Medical University of Sofia, Sofia, Bulgaria \\ ${ }^{3}$ Clinic of Endocrinology, Alexandrovska University Hospital, Medical University of Sofia, Sofia, Bulgaria
}

\section{Correspondence: Evgeni Mekov, Clinical Center for Pulmonary Diseases, St. Sofia SHATPD; Medi- cal University of Sofia, Sofia, 19 Acad. Ivan Geshov Blvd., Sofia 431, Bulgaria \\ E-mail:dr_mekov@abv.bg \\ Tel.: +359888 320476}

Received: 24 Jan 2016

Accepted: 25 March 2016

Published: 30 April 2016

Key words: COPD, diabetes, quality of life, lung function

Citation: Mekov EV, Slavova YG, Genova MP, Tsakova AD, Kostadinov DT, Minchev DD, Marinova DM, Boyanov MA. Diabetes mellitus type 2 in hospitalized COPD patients: impact on quality of life and lung function.

Folia Medica 2016;58(1);36-41, doi: 10.1515/folmed-2016-0005
Introduction: Diabetes mellitus (DM) is estimated to affect 2-37\% of COPD patients, results varying widely between studies. DM may also correlate with quality of life and lung function.

Aim: To examine correlations between DM and quality of life and lung function in COPD patients admitted to hospital with exacerbation of COPD.

Patients and methods: A hundred and fifty-two patients were included in the study. They were all examined for diabetes mellitus. All patients completed CAT and $\mathrm{MMRC}$ questionnaires and underwent spirometry.

Results: $13.2 \%$ (20/152) of patients received medications for DM. 21.7\% (33/152) had newly diagnosed DM and $30.9 \%(47 / 152)$ had prediabetes. DM is not associated with reduced quality of life and worse pulmonary function. However, untreated DM is associated with both reduced quality of life and worse pulmonary function. $\mathrm{HbA1c}$ is negatively correlated with FVC and positively correlated with CAT score.

Conclusions: COPD patients hospitalized for exacerbation are at high risk for impaired glucose metabolism. Untreated DM is associated with worse lung function and lower quality of life, which stresses the importance of screening for the disease. The patients may benefit from optimizing blood glucose level.

\section{INTRODUCTION}

Chronic obstructive pulmonary disease (COPD) is a preventable and treatable disease with significant extrapulmonary effects that may contribute to the severity in individual patients. COPD has been projected to become the fourth leading cause of death worldwide in 2030. The extrapulmonary comorbidities influence the prognosis of the patients with COPD. ${ }^{1}$

Type 2 diabetes mellitus (DM) is common in patients with COPD. According to the available studies the prevalence of DM in COPD patients varies between $2-37 \% .^{2}$

Available studies suggest that DM may have impact on quality of life $^{3}$ and lung function ${ }^{4-9}$ in COPD patients. However, some studies found no association between lung function and the presence of DM. ${ }^{10-12}$ There are not enough data to determine whether the results from these studies are applicable to specific subgroups of patients such as COPD patients admitted for exacerbation.

\section{AIM}

The aim of this study was to examine correlations between DM and quality of life and lung function in patients with COPD admitted for exacerbation.

\section{PATIENTS AND METHODS}

A total of 152 COPD patients hospitalized for exacerbation were studied for the presence of DM and prediabetes using well-established criteria for:

- Presence of DM: fasting plasma glucose $\geq 7.0$ $\mathrm{mmol} / \mathrm{L}$ or $2-\mathrm{h}$ plasma glucose $\geq 11.1 \mathrm{mmol} / \mathrm{L}$ during an oral glucose tolerance test (OGTT) or $\mathrm{HbA} 1 \mathrm{c} \geq 6.5 \%$ or on therapy. ${ }^{13}$

- Presence of prediabetes: fasting plasma glucose 5.6-6.9 $\mathrm{mmol} / \mathrm{L}$ or $2-\mathrm{h}$ plasma glucose 7.8-11.0 $\mathrm{mmol} / \mathrm{L}$ during an OGTT or HbAlc $\geq 5.7-6.4 \%{ }^{13}$ 
The diagnosis of COPD was made according to GOLD (Global Initiative for Chronic Obstructive Lung Disease) criteria. ${ }^{1}$ Data were gathered for age, sex, therapy for DM and COPD therapy. The patients completed CAT and mMRC questionnaires and underwent pre- and post-bronchodilator spirometry.

The inclusion criteria were post-bronchodilator spirometry obstruction defined as FEV1/FVC $<0.70$. All participants in this study signed informed consent.

The exclusion criteria were failure to comply with study procedures (no completed questionnaires, no medical and demographic information, no spirometry, no lab tests) or FEV1/FVC ratio > 0.70 after administration of bronchodilator.

\section{QuAlity OF LIFE}

Quality of life was assessed with the mMRC scale and CAT questionnaire. Patients were instructed that there were no right or wrong answers. All patients' questions were answered. Patients were classified according to GOLD as having less symptoms (CAT < 10 ) and breathlessness (mMRC grade $0-1$ ) and more symptoms $(\mathrm{CAT} \geq 10)$ and breathlessness (mMRC grade $\geq 2$ ). Because all patients were hospitalized for exacerbation there were only group $\mathrm{C}$ (high risk, less symptoms) and group D (high risk, more symptoms) patients according to GOLD. ${ }^{1}$

\section{PULMONARY FUNCTION TESTING}

The spirometry was performed using Minispir ${ }^{\circledR}$ New spirometer (MIR - Medical International Research, Italy). Patients were instructed to withdraw using short-acting $\beta 2$-agonists at least 6 hours, long-acting $\beta 2$-agonist at least 12 hours, long acting muscarinic antagonist 24 hours and short acting muscarinic antagonist 12 hours before the spirometry. ${ }^{14}$ Postbronchodilator spirometry testing was performed 15-30 min after inhalation of $400 \mathrm{mcg}$ salbutamol according to ERS/ATS recommendations. ${ }^{14}$ Pre- and post-test values were obtained for: FVC, FEV1, FEV1/FVC, FEV6, FEV1/FEV6, PEF, FEF2575, FEV3, FEV3/FVC as well as the difference between post/pre values (delta values). GLI (Global Lungs Initiative) predicted values were used (GLI-2012). Patients' obstruction were classified according to the severity of airflow limitation based on postbronchodilator FEV1 as follows: mild ( $\geq 80 \%$ predicted); moderate $(80>$ FEV $1 \geq 50 \%$ predicted $)$; severe $(50 \%>$ FEV $1 \geq 30 \%$ predicted $)$; very severe $(<30 \% \text { predicted })^{1}$

\section{BLOOD SAMPLES AND ANALYSES}

A venous blood sample was collected from each subject after 12-hour fasting. Blood samples were taken as late as possible before discharging (usually on days 6 or 7). Plasma glucose was measured with a Roche COBAS INTEGRA ${ }^{\circledR} 400$ plus analyzer and an enzymatic reference method with hexokinase. Glycated hemoglobin (HbA1c) was measured with a NycoCard device and boronate affinity assay. For patients without established DM a 75g OGTT was performed with blood samples for glucose taken at 1 and 2 hours.

\section{STATISTICAL ANALYSIS}

Statistical analysis was performed with SPSS for Windows, v. 22.0 (SPSS Inc., Chicago, IL, USA). Continuous variables were presented as mean \pm standard deviation and 95 confidence intervals $(95 \% \mathrm{CI})$ and categorical variables - as percentages. Chi-square test was used to determine the associations between categorical variables. Continuous variables were examined for normality by Shapiro-Wilk test. For normally distributed variables, differences between the groups were determined by independent-samples $t$-test for two samples and analysis of variance (ANOVA) for more than 2 samples. Mann-Whitney $\mathrm{U}$ test was used for abnormally distributed variables with 2 samples and Kruskal-Wallis test for variables with more than 2 samples. Significance value (pvalue) was set at 0.05 .

All patients signed informed consent. Medical University-Sofia Research Ethics Commission approved the study.

\section{RESULTS}

\section{Characteristics of PATIENTS}

A total of 152 COPD patients admitted for exacerbation were recruited from St. Sofia University Hospital for Pulmonary Diseases, Sofia, Bulgaria. Mean age of patients in this study was $65.1 \pm 9.9$ years. $71.1 \%(108 / 152)$ were males, $28.9 \%(44 / 152)$ were females; mean post-bronchodilator $\mathrm{FEV}_{1}$ was $55.34 \pm 19.5 \%$. $15.8 \%$ from the patients were never smokers, $57.9 \%$ - former smokers and $26.3 \%$ - current smokers.

\section{Prevalence of DM}

$13.2 \%(20 / 152)$ of patients received medications for diabetes. In $21.7 \%$ (33/152) there was evidence of newly diagnosed DM and 30.9\% (47/152) had prediabetes. Only $34.2 \%(52 / 152)$ of the studied patients had no DM or prediabetes. 37\% (40/108) of males had DM vs. $29.5 \%$ (13/44) of females but this difference did not reach statistical significance $(\mathrm{p}=0.379)$ (Table 1). 
Table 1. Presence of DM and prediabetes according to different factors

\begin{tabular}{ccccc}
\hline & $\begin{array}{c}\text { DM } \\
\text { \% }\end{array}$ & $\mathbf{p}$ & $\begin{array}{c}\text { Predia- } \\
\text { betes } \\
\text { \% }\end{array}$ & $\mathbf{p}$ \\
\hline All & 34.9 & 30.9
\end{tabular}

\section{Quality of life}

\begin{tabular}{lllll} 
CAT 0-9 & 28.0 & & 32.0 & 0.898 \\
CAT $\geq 10$ & 36.2 & & 30.7 & \\
mMRC 0 or 1 & 30.2 & & 30.2 & \\
mMRC $\geq 2$ & 37.4 & 0.376 & 31.3 & 0.886 \\
FEV1 & & & & \\
FEV1 $>50 \%$ & 36.3 & & 30.8 & 0.961 \\
FEV1 $<50 \%$ & 32.8 & 0.659 & 31.1 & \\
\hline
\end{tabular}

Table 2. Mean CAT score on every question and in total according to presence of DM

\begin{tabular}{|c|c|c|c|}
\hline DM & Mean CAT score & $\mathbf{N}$ & $\mathbf{p}$ \\
\hline $\mathrm{DM}-$ no & CAT1 2.10 & 99 & \multirow{2}{*}{0.947} \\
\hline DM - yes & CAT1 2.15 & 53 & \\
\hline DM - no & CAT2 1.97 & 99 & \multirow{2}{*}{0.502} \\
\hline DM - yes & CAT2 2.13 & 53 & \\
\hline DM - no & CAT3 2.56 & 99 & \multirow{2}{*}{0.262} \\
\hline DM - yes & CAT3 2.83 & 53 & \\
\hline $\mathrm{DM}-$ no & CAT4 3.51 & 99 & \multirow{2}{*}{0.229} \\
\hline DM - yes & CAT4 3.70 & 53 & \\
\hline $\mathrm{DM}-$ no & CAT5 1.24 & 99 & \multirow{2}{*}{0.277} \\
\hline $\mathrm{DM}-$ yes & CAT5 1.51 & 53 & \\
\hline DM - no & CAT6 1.48 & 99 & \multirow{2}{*}{0.310} \\
\hline $\mathrm{DM}-$ yes & CAT6 1.75 & 53 & \\
\hline DM - no & CAT7 1.46 & 99 & \multirow{2}{*}{0.681} \\
\hline DM - yes & CAT7 1.60 & 53 & \\
\hline $\mathrm{DM}-$ no & CAT8 2.63 & 99 & \multirow{2}{*}{0.171} \\
\hline DM - yes & CAT8 2.94 & 53 & \\
\hline $\mathrm{DM}-$ no & Total CAT 16.95 & 99 & \multirow{2}{*}{0.230} \\
\hline DM - yes & Total CAT 18.62 & 53 & \\
\hline
\end{tabular}

The patients with DM were significantly older (68.4 vs 63.3 years, $p=0.002$ ), including patients with new DM (68.1 vs 63.3 years, $p=0.013$ ). Presence of prediabetes was not associated with age (65.2 vs 61.6 years, $\mathrm{p}=0.068)$.
QUALITY OF LIFE RESULTS

Our study did not find difference between mMRC and CAT scores in relation to the presence of DM or prediabetes (Table 2). Prevalence of DM was not significantly different between patients with less symptoms (CAT 0-9) and breathlessness (mMRC 0 or 1) compared to patients with more symptoms $(\mathrm{CAT} \geq 10)$ and breathlessness $(\mathrm{mMRC} \geq 2)$ (all $\mathrm{p}>0.05$ ) (Table 1). However, all patients with untreated DM were in GOLD grade D, whereas $84.8 \%$ of the patients without DM were in GOLD grade $\mathrm{D}(\mathrm{p}=0.018)$.

Linear regression analysis showed $\mathrm{HbA} 1 \mathrm{c}$ as a risk factor for reduced quality of life measured with total CAT score $\left(\mathrm{R}=0.197, \mathrm{r}^{2}=0.039, \mathrm{p}=\right.$ $0.015, \mathrm{~B}=1.325,95 \%$ CI $0.261-2.390)$ with strongest impact on the sixth CAT question - confidence $\left(\mathrm{R}=0.215, \mathrm{r}^{2}=0.046, \mathrm{p}=0.008, \mathrm{~B}=0.281\right.$, 95\% CI 0.075-0.487). HbA1c is a risk factor for reduced quality of life in males $\left(\mathrm{R}=0.262, \mathrm{r}^{2}=\right.$ $0.069, \mathrm{p}=0.006, \mathrm{~B}=2.084,95 \%$ CI 0.606-3.561), but not in females $(\mathrm{p}>0.05)$ measured with total CAT score.

Table 3. Mean PFT values according to the presence of DM

\begin{tabular}{llccc}
\hline DM & Mean PFT & & N & p \\
\hline No & FEV1 & $55.52 \%$ & 99 & 0.882 \\
Yes & FEV1 & $55.02 \%$ & 53 & \\
No & FVC & $81.58 \%$ & 99 & \multirow{2}{*}{0.051} \\
Yes & FVC & $72.62 \%$ & 53 & \\
No & FEV1/FVC & 0.52 & 99 & \multirow{2}{*}{0.013} \\
Yes & FEV1/FVC & 0.57 & 53 & \\
No & FEV6 & $74.80 \%$ & 99 & \multirow{2}{*}{0.165} \\
Yes & FEV6 & $68.42 \%$ & 53 & \\
No & FEV1/FEV6 & 0.57 & 99 & \multirow{2}{*}{0.033} \\
Yes & FEV1/FEV6 & 0.61 & 53 & \\
No & PEF & $56.66 \%$ & 99 & \multirow{2}{*}{0.688} \\
Yes & PEF & $54.43 \%$ & 53 & \\
No & FEF2575 & $37.96 \%$ & 99 & \multirow{2}{*}{0.112} \\
Yes & FEF2575 & $42.11 \%$ & 53 & \\
No & FEV3 & $67.29 \%$ & 99 & 0.466 \\
Yes & FEV3 & $63.42 \%$ & 53 & \\
No & FEV3/FVC & 0.81 & 99 & \multirow{2}{*}{0.067} \\
Yes & FEV3/FVC & 0.84 & 53 & \\
\hline
\end{tabular}


Pulmonary Function test (PFT) RESUlts

Our study found no differences in FVC, FEV1, FEV6, PEF, FEF2575 and FEV3 according to the presence of DM. It should be noted that FVC difference is almost significant $(p=0.051)$. However, because of the latter there is significant difference in FEV1/FVC ratio $(p=0.013)$ and FEV1/FEV6 ratio $(p=0.033)$ (Table 3$)$. Prediabetes was not associated with impaired lung function (all $\mathrm{p}>0.05$ ).

Untreated (new) DM is associated with significantly lower FVC (68.48 vs. $81.58 \%, \mathrm{p}=0.008)$ and FEV6 (64.09 vs. $74.80 \%, p=0.027)$ when compared to patients without DM. Linear regression shows FVC is further decreased in males with untreated DM $\left(\mathrm{R}=0.293, \mathrm{r}^{2}=0.086, \mathrm{p}=0.004\right.$, $\mathrm{B}=-15.489,95 \%$ CI $-25.969 ;-5.008)$.

There is no difference in prevalence of DM in patients with FEV $1<50 \%$, when compared to patients with FEV1 $>50 \%(\mathrm{p}=0.659)$ or regarding GOLD stage $(p=0.861)$ (Table 1).

Linear regression analysis shows that $\mathrm{HbAlc}$ is a risk factor for lower FVC $\left(\mathrm{R}=0.166, \mathrm{r}^{2}=\right.$ $0.027, \mathrm{p}=0.041, \mathrm{~B}=-3.116,95 \% \mathrm{CI}-6.111-0.122$ ). This is valid for males $\left(\mathrm{R}=0.221, \mathrm{r}^{2}=0.049\right.$, $\mathrm{p}=0.022, \mathrm{~B}=-5.037,95 \%$ CI $-9.327-0.747)$ but not for females $(p>0.05)$.

\section{DISCUSSION}

Our study has not found difference between mMRC and CAT scores in relation to the presence of DM or prediabetes. Prevalence of DM is not significantly different between patients with less symptoms (CAT $0-9$ ) and breathlessness (mMRC 0 or 1 ) compared to patients with more symptoms $(\mathrm{CAT} \geq 10)$ and breathlessness $(\mathrm{mMRC} \geq 2)$. This is in contrast with the data about reduced quality of life in patients with $\mathrm{DM}^{3}$ but may be explained with COPD having higher negative impact on quality of life than DM (physical limitation due to shortness of breath) ${ }^{15}$ and ameliorating the effect in patients having the two diseases. Second, newly found DM which represents a significant percentage in the DM group is unlikely to be associated with diabetic complications (for example painful neuropathy, retinopathy etc.) that have already been associated with a reduced quality of life, independent of the presence of COPD. However, all patients with untreated DM are in GOLD grade D, whereas $84.8 \%$ of the patients with untreated DM are in GOLD grade D which is statistically significant.

This study shows $\mathrm{HbA} 1 \mathrm{c}$ as a risk factor for reduced quality of life with strongest impact on the sixth CAT question - confidence. HbAlc is a risk factor for reduced quality of life in males, but not in females measured with total CAT score.

In this study, presence of DM is not associated with reduced quality of life, whereas untreated DM is associated with worse quality of life. HbAlc shows weak positive correlation with CAT score. These results show the importance of screening for the disease and early treatment.

COPD is characterized by airway obstruction, which is not fully reversible. DM is associated with a reduction of lung volumes. ${ }^{4,5}$ Large epidemiological studies have found a correlation between lung volumes on one hand and duration of DM and the presence of complications on the other. ${ }^{6-9}$ It should be noted that some studies found no association between lung function and the presence of DM. ${ }^{10-12}$

Our study did not find differences in FVC, FEV1, FEV6, PEF, FEF2575 and FEV3 according to the presence of DM with FVC difference between the groups being almost significant. There is no difference in the prevalence of DM in patients with FEV $1<50 \%$, when compared to patients with FEV $1>50 \%$ or regarding GOLD stage. Prediabetes was not associated with impaired lung function.

However, untreated (new) DM is associated with significantly lower FVC and FEV6 when compared to patients without DM. FVC is further decreased in males with untreated DM.

Linear regression shows higher $\mathrm{HbAlc}$ is a risk factor for lower FVC in males but not for females.

DM in our study is not associated with deteriorated pulmonary function but untreated DM is associated with lower FVC and FEV6.

Table 4. Rate of fulfilled criteria for all and new DM

\begin{tabular}{lcc}
\hline & All DM & New DM \\
\hline Blood glucose 0' $\geq 7.0 \mathrm{mmol} / 1$ & $24.5 \%(\mathrm{n}=13)$ & $15.2 \%(\mathrm{n}=5)$ \\
Blood glucose 120' $\geq 11.1 \mathrm{mmol} / \mathrm{l}$ & $37.7 \%(\mathrm{n}=20)$ & $60.6 \%(\mathrm{n}=20)$ \\
HbA1c $\geq 6.5 \%$ & $75.5 \%(\mathrm{n}=40)$ & $90.9 \%(\mathrm{n}=30$ \\
On therapy & $37.7 \%(\mathrm{n}=20)$ & - \\
\hline
\end{tabular}


The present study, which examines DM prevalence in COPD patients hospitalized for exacerbation, is not without some limitations. COPD exacerbation is an acute condition which may alter the glucose metabolism. However, all tests were performed at relatively stable condition (as late as possible before discharging). Secondly, the average dose of systemic steroid was $40 \mathrm{mg}$ for 3 days, total 120 $\mathrm{mg}$ and subjects with DM usually receive only a single dose of $40 \mathrm{mg}$. Thirdly, lab tests were performed at least 48 hours after the last dose of systemic steroids. Also, $91 \%$ of patients with newly diagnosed diabetes had $\mathrm{HbA} 1 \mathrm{c} \geq 6.5 \%$ suggesting prolonged hyperglycemia (Table 4).

\section{CONCLUSIONS}

This study has found high prevalence of DM $(34.9 \%)$ in COPD patients. The presence of DM is not associated with reduced quality of life and worse pulmonary function. Untreated DM, however, is associated with worse quality of life and lung function which stresses the importance of screening for the disease. The patients may benefit from optimizing their blood glucose levels.

\section{ACKNOWLEDGMENTS}

This manuscript is part of a $\mathrm{PhD}$ project, which is partially funded by Medical University - Sofia, Sofia, Bulgaria (grant number 15-D/2014, project number 22-D/2014).

\section{REFERENCES}

1. Global Strategy for the Diagnosis, Management and Prevention of COPD, Global Initiative for Chronic Obstructive Lung Disease (GOLD) 2015. Available from: http://www.goldcopd.org/.

2. Mekov E, Slavova Y. Diabetes mellitus and metabolic syndrome in COPD - part 1: introduction and epidemiology. Thoracic medicine 2013;5(4):6-18.

3. Wandell P. Quality of life of patients with diabetes mellitus. Scand J Prim Health Care 2005;23:68-74.

4. Mishra G, Dhamgaye T, Tayade B, Amol B, Amit
S, Jasmin D. Study of pulmonary function tests in diabetics with COPD or asthma. Applied Cardiopulmonary Pathophysiology 2012;16:299-308.

5. Yeh F, Dixon AE, Marion S, et al. Obesity in adults is associated with reduced lung function in metabolic syndrome and diabetes: the Strong Heart Study. Diabetes Care 2011;34:2306-13.

6. Davis T, Knuiman M, Kendall P, Vu H, Davis WA. Reduced pulmonary function and its associations in type 2 diabetes: the Fremantle Diabetes Study. Diabetes Res Clin Pract 2000;50:153-9.

7. Engstrom G, Janzon L. Risk of developing diabetes is inversely related to lung function: a populationbased cohort study. Diabet Med 2002;19:167-70.

8. Klein B, Moss S, Klein R, Cruickshanks K. Is peak expiratory flow rate a predictor of complications in diabetes? The Wisconsin Epidemiologic Study of Diabetic Retinopathy. J Diabetes Complications 2001;15:301-6.

9. Klein B, Moss S, Klein R, Cruickshanks K. Peak expiratory flow rate: relationship to risk variables and mortality: the Wisconsin Epidemiologic Study of diabetic retinopathy. Diabetes Care 2001;24:1967-71.

10. Benbassat CA, Stern E, Kramer M, Lebzelter J, Blum I, Fink G. Pulmonary function in patients with diabetes mellitus. Am J Med Sci 2001;322:127-32.

11. Mori H, Okubo M, Okamura M, et al. Abnormalities of pulmonary function in patients with noninsulin dependent diabetes mellitus. Intern Med 1992;31:189-93.

12. Ozmen B, Celik P, Yorgancioglu A, Ozmen D, Cok G. Pulmonary function parameters in patients with diabetes mellitus. Diabetes Res Clin Pract 2002;57:209-11.

13. American Diabetes Association. Diagnosis and Classification of Diabetes Mellitus. Diabetes Care 2012;35:S64-S71.

14. Miller M.R, Hankinson J, Brusasco V, et al. Standardisation of spirometry. Eur Respir J 2005;26:319-38.

15. Arne M, Janson C, Janson S. Physical activity and quality of life in subjects with chronic disease: chronic obstructive pulmonary disease compared with rheumatoid arthritis and diabetes mellitus. Scand J Prim Health Care 2009;27(3):141-7. 


\title{
Сахарный диабет 2-го типа у госпитализированных пациентов с ХОБЛ (хроническая обструктивная болезнь легких): влияние на качество жизни и функции легких
}

\author{
Евгени В. Меков ${ }^{1}$, Янина Г. Славова ${ }^{1}$, Марианка П. Генова ${ }^{2}$, Аделина Д. Цакова ${ }^{2}$, \\ Димитр Т. Костадинов ${ }^{1}$, Делчо Д. Минчев ${ }^{1}$, Дора М. Маринова ${ }^{1}$, Михаил А. Боянов ${ }^{3}$ \\ ${ }^{1}$ Клинический центр легочных заболеваний, Специализированная больница активного лечения легочных заболеваний \\ Св. София, Медицинский университет, София, Болгария \\ ${ }^{2}$ Центральная клиническая лаборатория, Александровска университетская больница, Медицинский университет, София, \\ Болгария \\ ${ }^{3}$ Клиника эндокринологии, Александровска Университетская больница, Медицинский университет, София, Болгария
}

Введение: По некоторым оценкам сахарным диабетом (СД) страдают от 2 до 37\% пациентов с ХОБЛ, но результаты широко варьируются между различными исследованиями. СД может также иметь определенную связь с качеством жизни и легочной функцией.

Цель: Изучить корреляционные связи между СД и качеством жизни и функцией легких у больных ХОБЛ, госпитализированных с обострением ХОБЛ.

Пациенты и методы: В настоящее исследование было включено сто пятьдесят два пациента. Все они были обследованы на предмет сахарного диабета. Также все пациенты прошли КАТ - компьютерную аксиальную томографию и анкеты mMRC (Модифицированного Совета по медицинским исследованиям), а также прошли спирометрию.

Результаты: 13,2\% (20/152) пациентов получали лекарства для лечения СД. 21,7\% (33/152) впервые был поставлен диагноз СД и у 30,9\% (47/152) был констатирован преддиабет. СД не связан со снижением качества жизни и ухудшением легочной функции. Тем не менее, неконтролируемый СД связан с низким качеством жизни и ухудшением легочной функции. НbA1с (гликированный гемоглобин) отрицательно коррелирует с форсированной вентиляционной способностью и положительно коррелирует с оценкой по КАТ.

Заключение: У больных ХОБЛ, госпитализированных при обострении заболевания, высок риск нарушенного метаболизма глюкозы. Неконтролированный СД ассоциируется с ухудшением функции легких и снижением качества жизни, что подчеркивает важность скрининга заболевания. Оптимизация уровня глюкозы в крови может привести к повышению качества жизни пациентов.

Ключевые слова: ХОБЛ, диабет, качество жизни, легочная функция 